\title{
Alkali-silica reactivity of basaltic aggregates of Mesopotamia Argentina: case studies
}

\author{
Lenís Madsen $^{1}$ (D) Claudio Rocco $^{2} \cdot$ Darío Falcone $^{2,3} \cdot$ Francisco Locati $^{4} \cdot$ Silvina Marfil $^{1}$
}

Received: 1 August 2018 / Accepted: 9 January 2019

(C) Springer-Verlag GmbH Germany, part of Springer Nature 2019

\begin{abstract}
This work consists of two stages; first, studies were conducted to evaluate the potential reactivity of crushed material (6-20 mm fraction) from two quarries (named A and B) producing basaltic aggregates in the northeast of Argentina (Mesopotamia region, province of Corrientes). The studies included petrographic analysis, identification of expandable clay by X-ray diffraction, and standardized physical tests on mortar bars and concrete prisms to evaluate their potential reactivity. Also, dissolved silica was determined according to the chemical test method. Although the studied aggregates cannot be qualified in the same way based on the results of the physical tests, there is a direct relationship between the glass and expandable clay content in the samples (quarry A aggregate $>$ quarry $\mathrm{B}$ aggregate) and their behavior in the physical and chemical tests (higher values for aggregates A). In the second stage, two structures of the province of Corrientes were studied: an urban pavement (made with aggregate A) and an airport runway (made with aggregate B), both with signs of alkali-silica reaction (ASR). A visual survey was carried out and concrete cores were extracted. On the latter, physical tests, petrographic studies, and SEM-EDS determinations were performed to identify reaction products. In the urban pavement, aggregate A, used as coarse aggregate, and the presence of siliceous sandstones rich in chalcedony and microcrystalline quartz in the fine aggregate would have contributed to ASR development, while in the airport runway, the initial deterioration would have favored the ASR as a secondary process.
\end{abstract}

Keywords Basalt $\cdot$ Chalcedony $\cdot$ Smectite $\cdot$ Alkali-silica reaction

\section{Introduction}

Basaltic rocks are one of the main sources of coarse aggregates for concrete manufacture worldwide. In Argentina, these types of rocks are widely distributed and also occur as constituents of natural sands and gravel. They are one of the main sources of coarse aggregates for concrete manufacture due to their good physical and mechanical properties. However, in several regions of Argentina, as well as in other countries, such as Australia, Brazil, Czech Republic, China, Iceland, Italy, Japan, Mexico, New Zealand, Turkey and Portugal, concrete structures built with basaltic aggregate (airport runways, dams, pavements, among others) have deteriorated due to the development of the alkali-silica reaction (ASR; Guömundsson and Ásgeirsson 1975; Shayan and Quick 1988; Katayama et al. 1989, 1996; Marfil et al. 1998; Munhoz et al. 2008; Román et al. 2008; Vola et al. 2011).

Lenís Madsen

lenis.madsen@uns.edu.ar

Claudio Rocco

cgrocco@ing.unlp.edu.ar

Darío Falcone

durabilidad@lemit.gov.ar

Francisco Locati

flocati@unc.edu.ar

Silvina Marfil

smarfil@uns.edu.ar
CGAMA (CIC-UNS) - Geology Department - UNS, San Juan 670, 8000 Bahía Blanca, Argentina

2 Área Departamental Construcciones, Facultad de Ingeniería, UNLP, Calle 48 y 115, 1900 La Plata, Argentina

3 LEMIT-CIC, Laboratorio de Entrenamiento Multidisciplinario para la Investigación Tecnológica, Av. 52 e/121 y 122, 1900 La Plata, Argentina

4 CICTERRA (CONICET-UNC), Av. Vélez Sarsfield 1611, X5016GCA Córdoba, Argentina 
The ASR is the chemical reaction that occurs between the hydroxyl ions $\left(\mathrm{OH}^{-}\right)$present in the concrete pore solution, together with alkaline ions that also participate in the reaction (mainly $\mathrm{Na}^{+}, \mathrm{K}^{+}$and $\mathrm{Ca}^{2+}$ ), and the Si-O-Si networks of the reactive siliceous aggregates (Ichikawa and Miura 2007).

This process produces hydrated alkaline silicates that expand in the presence of moisture, causing internal cracking. As the concrete deteriorates, its permeability increases and water penetration contributes to the reaction.

This cycle continues until the concrete deteriorates past the point of serviceability (ACI 1992). According to Wakizaka (2000), the factors that control the dissolution of silica in the reactive aggregates are silica content, thermodynamic properties, specific surface and crystallinity.

According to Katayama et al. (1989), when the silica content of the rock is more than $50 \%$, the basalt can be potentially reactive and should be treated as an andesite in terms of reactivity. Generally, the reactivity of these rocks is attributed to the presence of amorphous material (volcanic glass) or microcrystalline silica present in intercrystalline voids (Wakizaka 2000; St John et al. 1998; Marfil and Maiza 2001; Korkanç and Tuğrul 2005; Goguel 1995; Valduga et al. 2006; Tiecher et al. 2009). These phases react quickly with the alkaline hydroxides present in the pore solution, dissolving easily to generate hydrated alkaline silicates that cause concrete deterioration (Wakizaka 2000; Tiecher et al. 2009; Broekmans and Jansen 1998; Leemann and Holzer 2005). However, there are detailed studies that show that although the interstitial material (mesostasis) can present the optical characteristics of amorphous materials, it corresponds to a mixture of volcanic glass and other crystalline interstitial phases such as potassium feldspar, quartz and clays (Gomes 1996; Tiecher 2006; Tiecher et al. 2012).

The standard test methods commonly used to evaluate the potential alkali reactivity (accelerated and not accelerated) do not always have matching results, especially for basaltic rocks (Couto 2008; Sanchez 1988). On the other hand, there are also aggregates that test as potentially reactive in the laboratory, but, in concrete structures, are nonreactive (Tiecher et al. 2012). Therefore, both the methods used to evaluate the potential reactivity and the determination of the phases that participate in the ASR are still the object of worldwide discussion.

The purpose of the present work is to compare two basaltic rocks from the northeast of Argentina, with different potential alkali reactivity using petrographic, physical and chemical methods, and evaluate their performance in concrete, studying two structures built with these materials.

\section{Location and geological setting}

The basaltic rocks studied are located in the province of Corrientes (Argentina). This province, together with
Misiones and Entre Ríos provinces, forms part of the Argentine Mesopotamia, limited to the west by the Paraná River and to the east by the Uruguay River (Fig. 1a).

In this region, outcrops of the Chacoparanaense basin occur (Montaño et al. 1998; Silva Busso 1999), which are composed of sedimentary and volcanic rocks with ages from Paleozoic to recent. The thickness is variable; the greatest depth is in the south, where it reaches more than $4500 \mathrm{~m}$ (Favetto et al. 2004).

The volcanism in the area took place from the end of the Jurassic period and mainly during the Lower Cretaceous, associated with the opening of the Atlantic Ocean, forming the great Paraná igneous province (in South America).

This dominantly eruptive basaltic event, mainly tholeiitic, of regional magnitude, extended over approximately $1,000,000 \mathrm{~km}^{2}$ covering part of Argentine territory and the bordering countries, namely, Brazil, Uruguay and Paraguay.

An important feature of this basin is the basaltic succession (Fig. 1b) called Serra Geral Formation, which is composed of thick interstratified basaltic spills with clastic sedimentary rocks, occasionally with thermal metamorphism (Favetto and Pomposiello 2010).

The basalt outcrops next to the Uruguay River to the east of Misiones and Corrientes and northeast of Entre Ríos. The thickness ranges between 800 and $1000 \mathrm{~m}$, reaching $1930 \mathrm{~m}$ in Brazil (Fili et al. 1998).

These basalts are mainly compact, with dominant finegrained texture and dark gray to black color (Pezzi and Mozetic 1989). Marfil et al. (2010) identified in the area a floor, usually of vesicular structure of very fine grains, with assimilation of the substrate, silicification by precipitation of cryptocrystalline silica from meteoric waters, and very vitreous. In the central part of the lava flows, the crystal size is greater, the texture is ophitic to subophitic, with nearly no glass, and the rock is holocrystalline.

At higher levels, the lithological characteristics are similar to those mentioned for the middle sector. Crystal development is slightly smaller, although the exogenous processes altered the rocks and developed an intersertal texture with argilization of the original minerals and glass.

Due to this great variability in the texture and volcanic glass content, it is important to carry out detailed studies of quarry fronts currently in operation in order to evaluate their potential reactivity.

\section{Materials and methods}

\section{Materials}

Two basalt quarries currently mined for concrete aggregates were studied. They are located in the province of Corrientes (Argentina). One is next to the city of Curuzú Cuatiá (quarry 

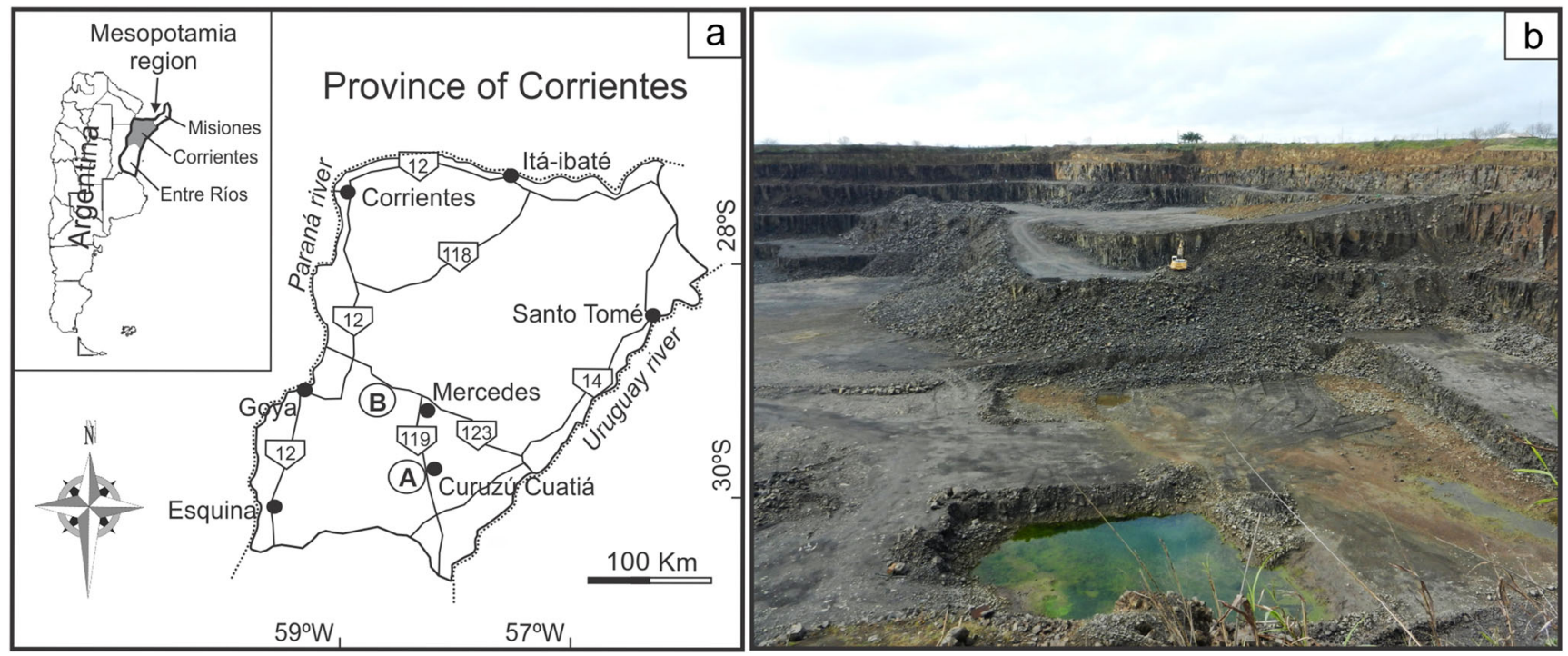

Fig. 1 a Location of quarries. b Front of quarry A

A) and the second one in the center of the province, to the west of Mercedes city (quarry B; Fig. 1a).

In each quarry, visual observations of the fronts were made. Representative samples of the crushed material (6-20 mm fraction) were taken $\left(\sim 2 \mathrm{~m}^{3}\right)$ and reduced by quartering in the laboratory to obtain the portions used in the different tests.

Also, two concrete structures of the region were studied: an urban pavement of Curuzú Cuatiá city built in 1997, and a concrete pavement of Corrientes Airport (Fig. 1a), both deteriorated by ASR. In the former, the rock from quarry A was used as coarse aggregate, while in the latter, the aggregate came from quarry B.

\section{Methods}

The aggregate samples of the two quarries were studied by:

- Petrographic examination (IRAM 1649, 2008. Argentine Institute of Standardization and Certification): A petrographic and mineralogical study of the samples was carried out following the guidelines of the standard (similar to ASTM C295, 2008). An Olympus trinocular stereomicroscope SZ-PT and a trinocular Leica DM750P polarization microscope were used. In order to complement the mineralogical characterization and to determine the presence of expandable clays, X-ray diffraction (XRD) studies were carried out on the fraction $<2 \mu \mathrm{m}$ on airdried samples, treated with ethylene glycol and calcined at $500{ }^{\circ} \mathrm{C}$. A Rigaku D-Max III-C diffractometer, working at $35 \mathrm{kV}$ and $15 \mathrm{~mA}$, using $\mathrm{Cu} \mathrm{K} \alpha_{1,2}$ radiation $(\lambda=$ $1.541840 \AA$ ) filtered with a graphite monochromator in the diffracted beam, from $3^{\circ}$ to $35^{\circ} 2 \theta$ with increments of $0.04^{\circ} 2 \theta$ and a counting time of $1 \mathrm{~s}$ per step, was employed. In addition, the percentage of volcanic glass and clays in each sample was determined with modal analysis on thin sections made with the crushed material (10 fields were analyzed).

- Chemical analyses of major and minor elements were carried out on the 6-20 $\mathrm{mm}$ fraction of the two quarries at Bureau Veritas Mineral Laboratories (Canada).

- Chemical test method (IRAM 1650, 1968): Dissolved silica was determined for each sample according to the procedure of the standard (similar to ASTM C289, 2007). The samples were crushed to pass a \# $50(\sim 300 \mathrm{~mm})$ sieve and be retained on a \# $100(\sim 150 \mathrm{~mm})$ sieve, then washed and dried at $105{ }^{\circ} \mathrm{C}$. Twenty-five grams was placed in $1 \mathrm{~N} \mathrm{NaOH}$ solution at $80^{\circ} \mathrm{C}$ for $24 \mathrm{~h}$. An aliquot was brought to acidic $\mathrm{pH}$, and dissolved silica was determined by gravimetry.

Table 1 Chemical analysis of the aggregates studied (6-20 mm)

\begin{tabular}{|c|c|c|c|c|c|c|c|c|c|c|c|}
\hline \multirow[t]{2}{*}{ Quarry } & \multicolumn{7}{|c|}{ Major elements (\%) } & \multicolumn{3}{|c|}{ Minor elements (\%) } & \multirow[t]{2}{*}{ LOI } \\
\hline & $\mathrm{SiO}_{2}$ & $\mathrm{Al}_{2} \mathrm{O}_{3}$ & $\mathrm{Fe}_{2} \mathrm{O}_{3}$ & $\mathrm{MgO}$ & $\mathrm{CaO}$ & $\mathrm{Na}_{2} \mathrm{O}$ & $\mathrm{K}_{2} \mathrm{O}$ & $\mathrm{TiO}_{2}$ & $\mathrm{P}_{2} \mathrm{O}_{5}$ & $\mathrm{MnO}$ & \\
\hline A & 49.61 & 12.41 & 15.90 & 4.40 & 8.41 & 2.60 & 1.37 & 3.51 & 0.36 & 0.22 & 0.8 \\
\hline $\mathrm{B}$ & 55.19 & 12.39 & 14.28 & 3.04 & 6.55 & 3.13 & 1.95 & 1.82 & 0.26 & 0.20 & 0.9 \\
\hline
\end{tabular}

LOI loss on ignition 
Fig. 2 Diffraction patterns of the fraction $<2 \mu \mathrm{m}$ of sample A (above) air-dried, glycolated and calcined; and sample B (below), air-dried

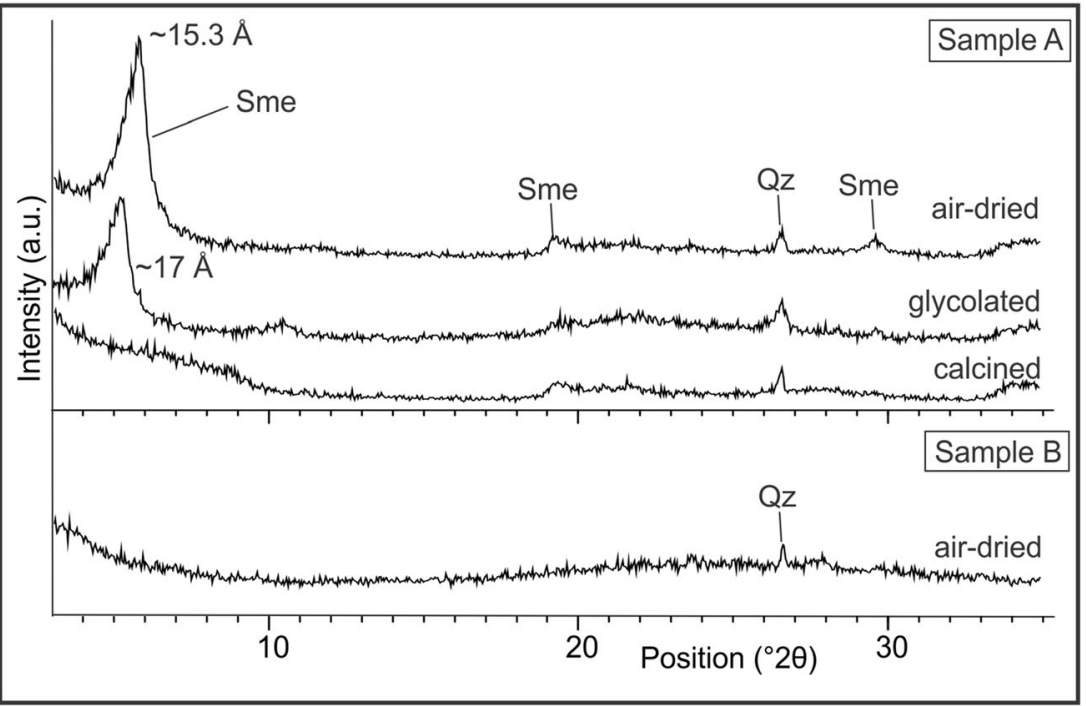

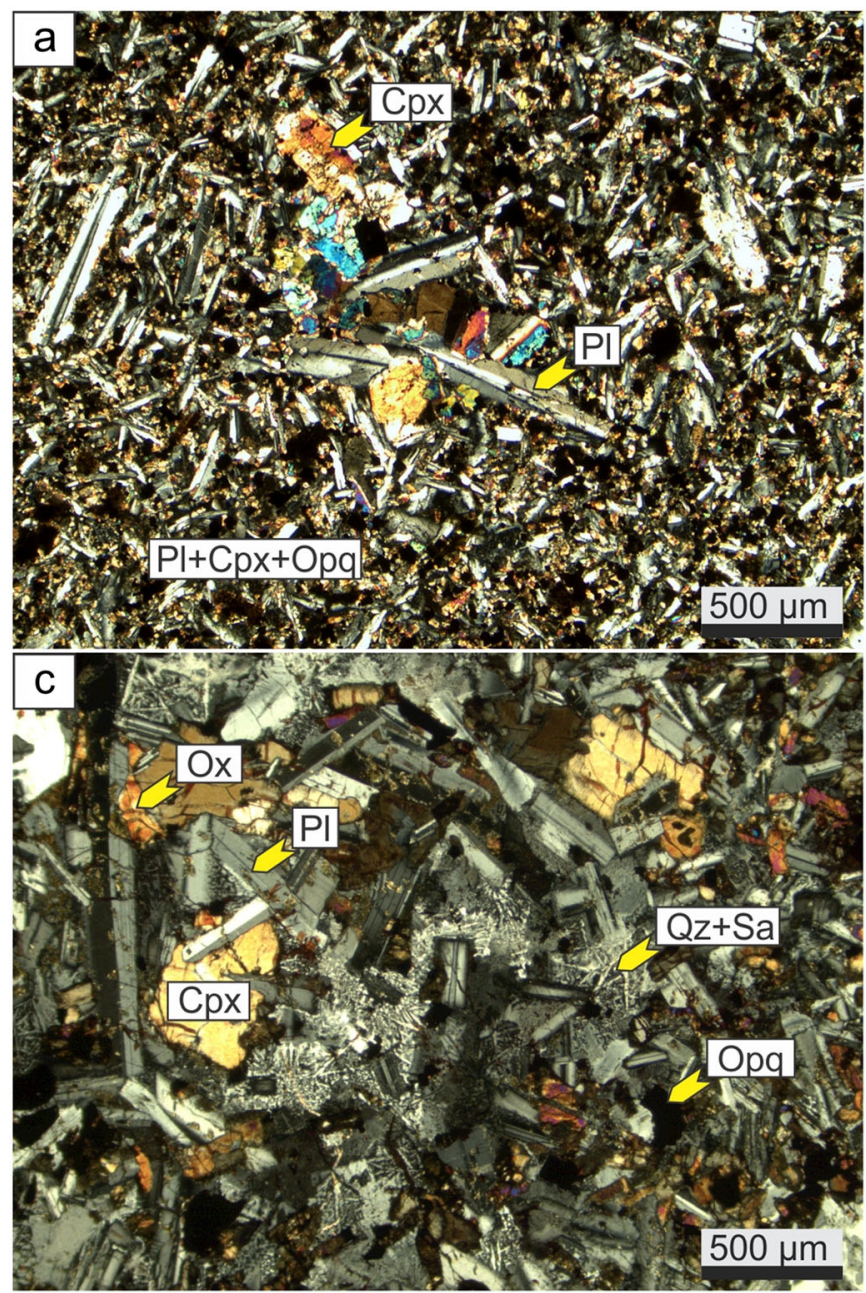

Fig. 3 Photomicrographs: a Texture of quarry A rock (XN). b Detail of the interspaces filled with smectites $(/ / \mathrm{N})$. c Texture of quarry B rock $(\mathrm{XN})$. d Detail of the interspaces with association of quartz and

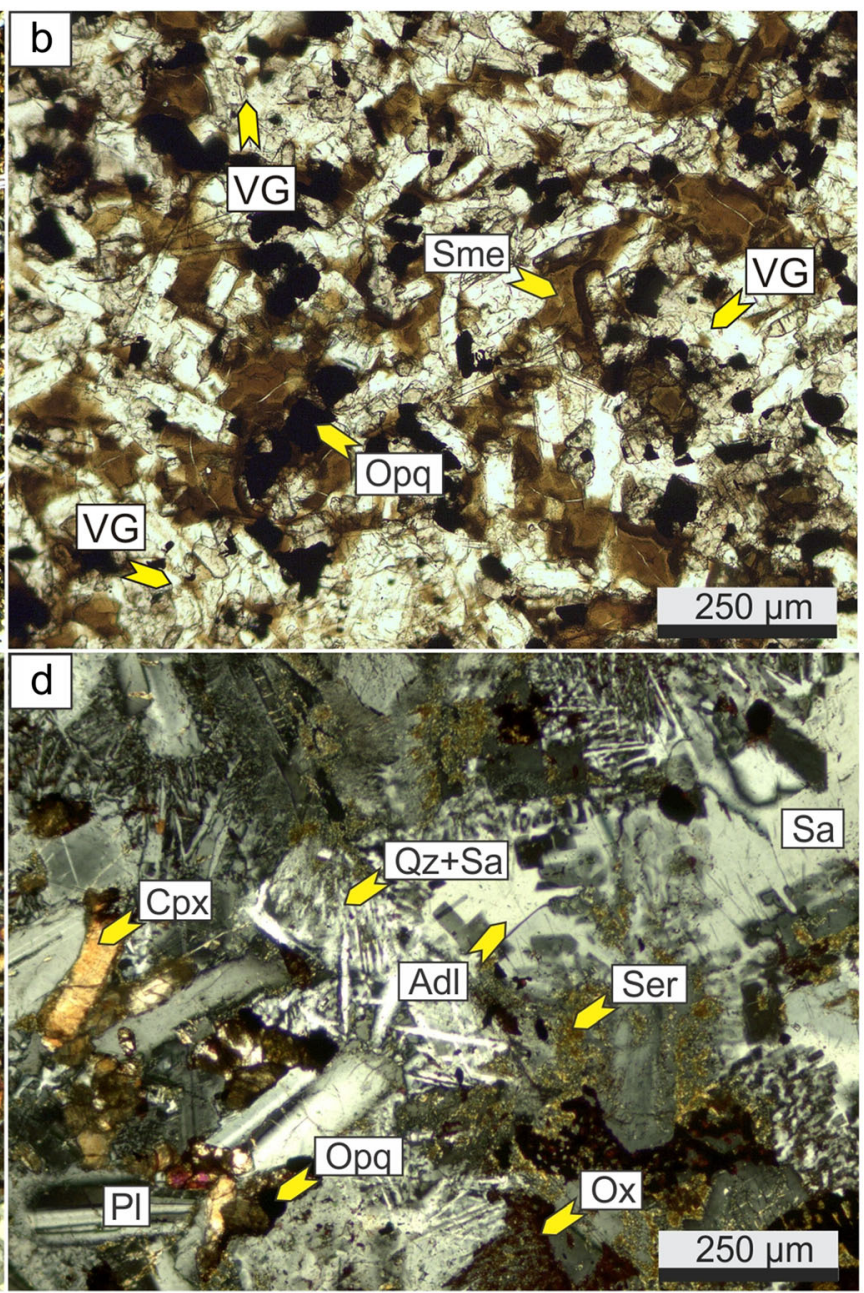

potassium feldspar $(\mathrm{XN}) . / / \mathrm{N}$ : parallel nicols. $\mathrm{XN}$ : crossed nicols. VG: volcanic glass. Mineral abbreviations according to Whitney and Evans (2010) 
Table 2 Petrographic characteristics

\begin{tabular}{|c|c|c|c|c|c|c|}
\hline Sample & Rock & Minerals and relative abundance & Texture & Mesostasis (\%) & Glass $(\%)$ & Smectite $(\%)$ \\
\hline A & Basalt & $\mathrm{Pl}>\mathrm{Cpx}>\mathrm{Opq}>\mathrm{Sme}>\mathrm{Ap}>\mathrm{Ox}>\mathrm{Ser}$ & Intersertal & $\approx 8$ & 2.5 & 2.2 \\
\hline $\mathrm{B}$ & Andesitic basalt & $\mathrm{Pl}>\mathrm{Cpx}>\mathrm{Sa}>\mathrm{Opq}>\mathrm{Qz}>\mathrm{Adl}>\mathrm{Ox}>\mathrm{Ser}>\mathrm{Ap}>$ Sme & Intergranular & $\approx 3$ & 0.5 & $<1$ \\
\hline
\end{tabular}

- Accelerated mortar bar test (IRAM 1674, 1997): This method is similar to that proposed in ASTM C1260 (2014). To obtain the specific sizes, the aggregate was crushed, sieved and washed. One part of normal portland cement (NPC 40 ) with $0.82 \%$ of alkali equivalent content and 2.25 parts of aggregate with water-to-cement ratio 0.47 were used. For the mixing, demineralized water was used. Three molds of $25 \mathrm{~mm} \times 25 \mathrm{~mm} \times 300 \mathrm{~mm}$ were used. After $24 \mathrm{~h}$ in a moist chamber, the specimens were demolded, and a first reference reading was taken. Then, they were immersed in water at $80{ }^{\circ} \mathrm{C} \pm 2{ }^{\circ} \mathrm{C}$ in a storage container for $24 \mathrm{~h}$, and a zero reading was taken. Finally, they were immersed in a $1 \mathrm{~N} \mathrm{NaOH}$ solution and placed in an oven at $80{ }^{\circ} \mathrm{C} \pm 2{ }^{\circ} \mathrm{C}$, taking periodic readings for 16 days (14 days in $\mathrm{NaOH}$ solution).

- Concrete prism test (IRAM 1700, 2013): This method is similar to that proposed by ASTM C1293 (2018). Coarse aggregate $(6-20 \mathrm{~mm}$ fraction) specified by the standard was used. The material was washed, the densities were determined and the amounts were calculated for $1 \mathrm{~m}^{3}$ concrete. NPC 40 with $0.82 \%$ of alkali equivalent content, and sand with a fineness modulus of 2.7 , considered nonreactive when evaluated according to IRAM 1674 (1997) standard, were used. The alkali equivalent content was increased with $\mathrm{NaOH}$ (purity $98.15 \%$, up to $5.25 \mathrm{~kg} / \mathrm{m}^{3}$ ). For the mixing, demineralized water was used. The cement content was $420 \mathrm{~kg} / \mathrm{m}^{3}$, the fine aggregate/coarse aggregate ratio $=40 / 60$ and the $\mathrm{w} / \mathrm{c}$ ratio varied between 0.42 and 0.45 . To obtain an adequate consistency to correctly fill the molds, $0.44 \mathrm{w} / \mathrm{c}$ was chosen. Three molds of $75 \mathrm{~mm} \times 75 \mathrm{~mm} \times 275 \mathrm{~mm}$ were used. After $24 \mathrm{~h}$, the specimens were demolded, and the first reference reading was taken. They were then wrapped in saturated cotton cloth covered with polyethylene film, placed in a nylon bag with $5 \mathrm{ml}$ of distilled water and hermetically sealed. The set of prisms was placed in a sealed container at a temperature of $23 \pm 2^{\circ} \mathrm{C}$ to perform, after $24 \mathrm{~h}$, the initial reading. Subsequently, they

Table 3 Dissolved silica determined according to the chemical test method (IRAM 1650, 1968)

\begin{tabular}{lc}
\hline Sample & Dissolved silica (mg) \\
\hline A & 37.0 \\
B & 7.0 \\
\hline
\end{tabular}

were placed in the moist chamber at $38 \pm 2{ }^{\circ} \mathrm{C}$ for 1 year, taking periodic readings after $1,2,4,8,13,18,26,39$ and 52 weeks. In each measurement, the containers were removed $24 \mathrm{~h}$ before to stabilize the reading temperature at $22 \pm 2^{\circ} \mathrm{C}$.

- Accelerated concrete prism test (IRAM 1700, 2013): This method consists of making concrete prisms as mentioned before (in the non-accelerated version), raising the temperature from $38{ }^{\circ} \mathrm{C} \pm 2{ }^{\circ} \mathrm{C}$ to $60{ }^{\circ} \mathrm{C} \pm 2{ }^{\circ} \mathrm{C}$ in a similar way to that proposed by RILEM standard AAR-4.1 (Nixon and Sims 2016). Periodic readings at 5, 8, 10, 13,15 and 20 weeks were taken. The study periods are frequently extended, increasing the times established by the standards, to obtain more information.

The two concrete structures analyzed were studied by:

- Visual inspection. It focused on determining the type and degree of cracking, its distribution in the structure, the recognition of cracks associated with ASR, contraction phenomena on the surface of the pavement, and plastic or autogenous contraction.

- Five concrete cores of $15 \mathrm{~cm}$ diameter were extracted from each structure, in accordance with the recommendations of IRAM 1551 (2000) standard. A visual inspection was carried out, and physical properties were determined (dry density, saturated density, dry surface, absorption, porosity, loss on ignition, unit content of dry fine and coarse aggregates) according to ASTM C 642 (2013).

For the determination of the physical properties, subsamples were obtained by cutting the cores with a cutting disc provided with a diamond crown.

- Subsequently, observations with a stereomicroscope and a polarizing optical microscope on thin sections were made. The samples were then polished (abrasive up to $1 \mu \mathrm{m})$ and metallized with carbon for observation with

Table 4 Results of the accelerated mortar bar test (IRAM 1674, 1997)

\begin{tabular}{llllll}
\hline Sample & \multicolumn{5}{l}{ Expansion (\%) at age (days) } \\
\cline { 2 - 6 } & 6 & 9 & 12 & 14 & 16 \\
\hline A & 0.137 & 0.337 & 0.432 & 0.464 & 0.498 \\
B & 0.030 & 0.095 & 0.136 & 0.165 & 0.207 \\
\hline
\end{tabular}




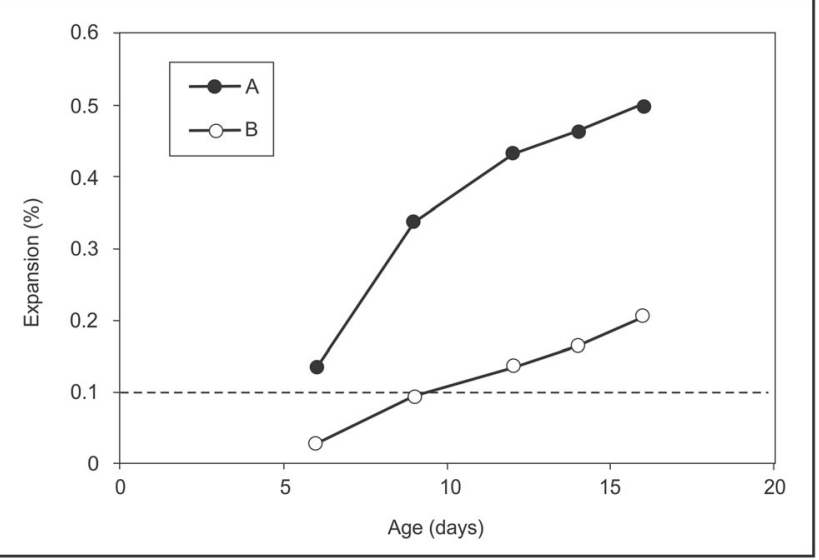

Fig. 4 Expansion curves according to the accelerated mortar bar method (IRAM 1674, 1997)

a scanning electron microscope (SEM, LEO EVO 40$\mathrm{XVP}$ ), working at $20 \mathrm{keV}$, equipped with an energy dispersive X-ray spectrometer (EDS) detector for semiquantitative chemical analysis of microareas.

Finally, the broken surfaces of concrete cores were observed by SEM-EDS to study the morphology and the semiquantitative chemical composition of the different reaction products.

\section{Results}

\section{Aggregate samples}

\section{Petrographic examination and chemical analysis}

Basaltic rocks can present variable composition and texture. Table 1 shows the results of the chemical analysis of major and minor elements. It can be seen that sample A has lower $\mathrm{SiO}_{2}$ content than sample $\mathrm{B}$, while the other components have similar percentages.

Considering the total alkali vs. silica contents (Le Bas et al. 1986), the rocks plot into the field of basalts, moving towards the intermediate limit with higher $\mathrm{SiO}_{2}$ values (andesitic basalt) in sample B.

The rocks analyzed are compact basalts, lithologically homogeneous, with irregular cracks, fine grains, dark gray to black color, and aphanitic. They consist of a fine-grained mineralogical association, with intersertal to intergranular texture. They are composed of subhedral plagioclase tablets, fractured, with corroded and twinned edges. Frequently, these phenocrysts are partially albitized. In the intercrystalline spaces, partially altered clinopyroxenes (iron oxides/hydroxides), associated with opaque minerals, were observed. Some sectors present clay minerals with low birefringence, opaque minerals and apatite, the latter arranged in fine needles without preferential orientation in both rocks. In some areas, the paste is vitreous, conserving its isotropic characteristics. The alteration processes, especially those that affected the volcanic glass, generated clay minerals that are also located in the microcracks of the primary minerals. By XRD, the clay present was determined as smectite-type (expandable), being abundant in aggregate A, while in aggregate $\mathrm{B}$ it was not recognized by this method due to the low proportion in the sample (Fig. 2).

Figure 3 shows the textural differences between both samples. The rock of quarry A has intersertal texture, and the grain size ranges between $200 \mu \mathrm{m}$ and $300 \mu \mathrm{m}$.

In some sectors, xenoliths of a rock of similar composition, greater crystal development and microcrystalline texture were observed. They are composed of plagioclase crystals, clinopyroxenes and opaque minerals (Fig. 3a).

In the intercrystalline spaces, smectite is recognized as the alteration product of volcanic glass, together with opaque minerals (Fig. 3b). In the rock of quarry B, the content of opaque minerals is lower, although the proportion of iron oxides/hydroxides associated mainly with clinopyroxenes is higher. In the intercrystalline plagioclase spaces $(300$ $600 \mu \mathrm{m}$ ) locally sericitized, fresh sanidine crystals were recognized, sometimes associated with microcrystalline quartz $(<$ $62 \mu \mathrm{m}$ ) developing poikilitic and micrographic textures (Fig. 3c). Quartz, associated with adularia, was also identified (Fig. 3d). The presence of these minerals explains the higher $\mathrm{SiO}_{2}$ content of this sample with respect to sample A. No xenoliths were recognized.

Table 2 lists the glass and clay content determined by modal analysis on the crushed basaltic rocks. The sample from quarry A has nearly $3 \%$ of glass, considered as a limit value to qualify an aggregate as potentially reactive according to Argentine regulations (IRAM 1531, 2016). On the other hand, the crushed rock from quarry B presents values below the mentioned limit. The clay content does not exceed the

Table 5 Results of the concrete prism test (IRAM 1700, 2013)

\begin{tabular}{llllllllll}
\hline Sample & \multicolumn{2}{l}{ Expansion (\%) at age (weeks) } & & & & \\
\cline { 2 - 8 } & 1 & 2 & 4 & 8 & 13 & 18 & 26 & 39 & 52 \\
\hline A & 0.003 & 0.003 & 0.005 & 0.007 & 0.008 & 0.009 & 0.023 & 0.054 & 0.089 \\
B & 0.005 & 0.003 & 0.003 & 0.005 & 0.005 & 0.002 & 0.004 & 0.004 & 0.003 \\
\hline
\end{tabular}


Fig. 5 Expansion curves according to the concrete prism method (IRAM 1700, 2013)

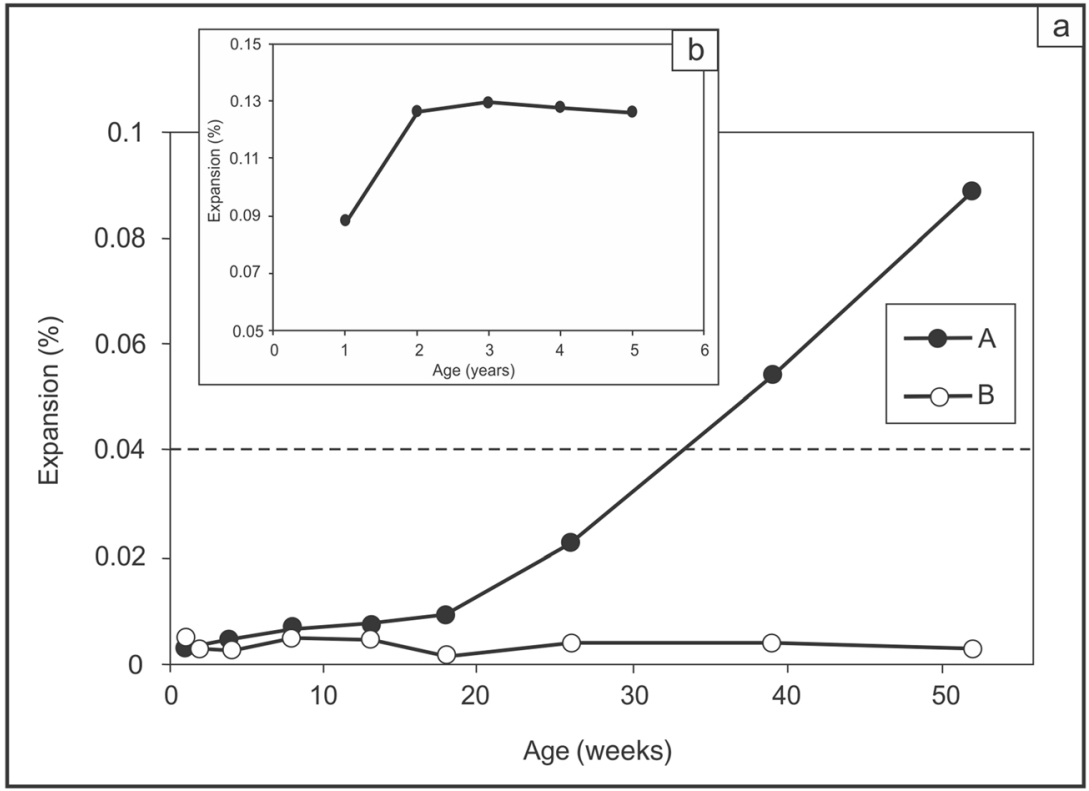

maximum value $(5 \%)$ established by the above-mentioned standard for both quarries; however, the value in sample A is more than twice that of sample B.

\section{Determination of dissolved silica (IRAM 1650, 1968)}

According to previous work on this test and type of rock (Rocco et al. 2012), values higher than $20 \mathrm{mg}$ allow classifying the rocks as potentially reactive. The results show that the dissolved silica content is higher in aggregate $\mathrm{A}$, while in $\mathrm{B}$, it is $<10 \mathrm{mg}$ (Table 3 ).

\section{Accelerated mortar bar test (IRAM 1674, 1997)}

Table 4 lists the expansion results of the mortar bars corresponding to the crushed rock samples from the two quarries. Figure 4 shows that both samples have expansion values that exceed the maximum limit of $0.10 \%$ established to qualify the aggregates as potentially reactive, according to this test. The quarry B aggregate showed an expansion value of $0.207 \%$ at 16 days, while the aggregate A expansion was $0.498 \%$.

Table 6 Results of the accelerated concrete prism method (IRAM 1700, 2013)

\begin{tabular}{lllllll}
\hline Sample & \multicolumn{6}{l}{ Expansion (\%) at age (weeks) } \\
\cline { 2 - 7 } & 5 & 8 & 10 & 13 & 15 & 20 \\
\hline A & 0.017 & 0.023 & 0.026 & 0.030 & 0.035 & 0.037 \\
B & 0.003 & 0.008 & 0.009 & 0.010 & 0.010 & 0.010 \\
\hline
\end{tabular}

\section{Concrete prism test (IRAM 1700, 2013)}

Table 5 and Fig. 5a show the expansion results for both samples up to 52 weeks. It can be seen that until 18 weeks they both have a similar behavior; however, the expansion of the quarry A aggregate then increases almost linearly up to $0.089 \%$ at 1 year, exceeding the maximum of $0.04 \%$ established by the standard, qualifying the aggregate as potentially reactive.

Considering that sample A shows a marked positive trend from 18 weeks onwards, the test was extended until 5 years of age to evaluate the evolution of that trend (Fig. 5b). It is observed that the expansion increased until 2 years and then stabilized.

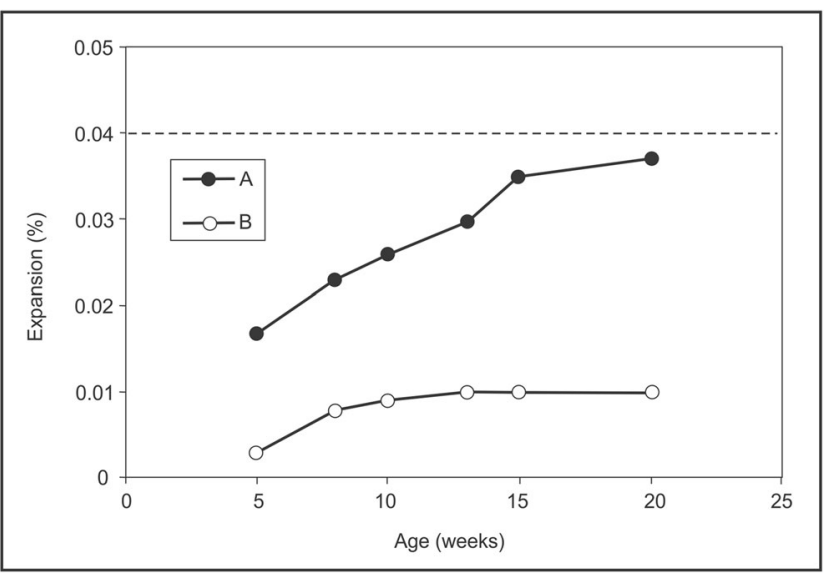

Fig. 6 Expansion curves according to the accelerated concrete prism method (IRAM 1700, 2013) 
Table 7 Visual inspection of the concrete pavement (Curuzú Cuatiá city)

\begin{tabular}{|c|c|c|c|c|}
\hline \multirow[t]{2}{*}{ Structure } & \multicolumn{3}{|c|}{ Presence of cracks and deterioration degree } & \multirow[t]{2}{*}{ Observations } \\
\hline & $\begin{array}{l}\text { Map cracks } \\
\text { attributable to } \\
\text { surficial mortar } \\
\text { contraction }\end{array}$ & $\begin{array}{l}\text { Plastic or } \\
\text { autogenous } \\
\text { contraction }\end{array}$ & $\begin{array}{l}\text { Map cracks } \\
\text { attributable to } \\
\text { deleterious reactions } \\
\text { (ASR) }\end{array}$ & \\
\hline $\begin{array}{l}\text { Concrete pavement } \\
\text { (Curuzú Cuatiá city, } \\
\text { Corrientes, Argentina) }\end{array}$ & Yes - M & No & Yes - S & $\begin{array}{l}\text { Shallow map cracks in the mortar, of moderate severity and } \\
\text { with longitudinal extension, attributable to severe } \\
\text { deleterious reactions (ASR), with structural damage. }\end{array}$ \\
\hline
\end{tabular}

Degree of cracking: $\mathrm{L}=$ light; $\mathrm{M}=$ moderate; $\mathrm{S}=$ severe

\section{Accelerated concrete prism test (IRAM 1700, 2013)}

Table 6 and Fig. 6 show the expansion results for the samples at 20 weeks. It can be observed that up to week 10 both have a similar behavior, but from week 13 onwards the aggregate from quarry B stabilizes, while that of quarry A continues expanding. However, none of the aggregates exceeds the maximum limit established by the standard for rapidly reactive aggregates $(0.04 \%$ at the age of 13 weeks; IRAM 1531 , 2016), qualifying both samples as nonreactive.
Fig. 7 a Longitudinal cracks in concrete slabs. b Concrete core with horizontal and vertical map cracks. $\mathbf{c}$ Reaction rims in the coarse aggregates with associated whitish material. $\mathbf{d}-\mathbf{f}$

Photomicrographs of concrete. $\mathbf{d}$ Coarse basaltic aggregate in noncarbonated cement paste $(\mathrm{XN})$. e Chalcedony and microcrystalline quartz coarse aggregate with reaction rims $(\mathrm{XN})$. f Same sector with //N. CP: cement paste. BA: basaltic aggregate
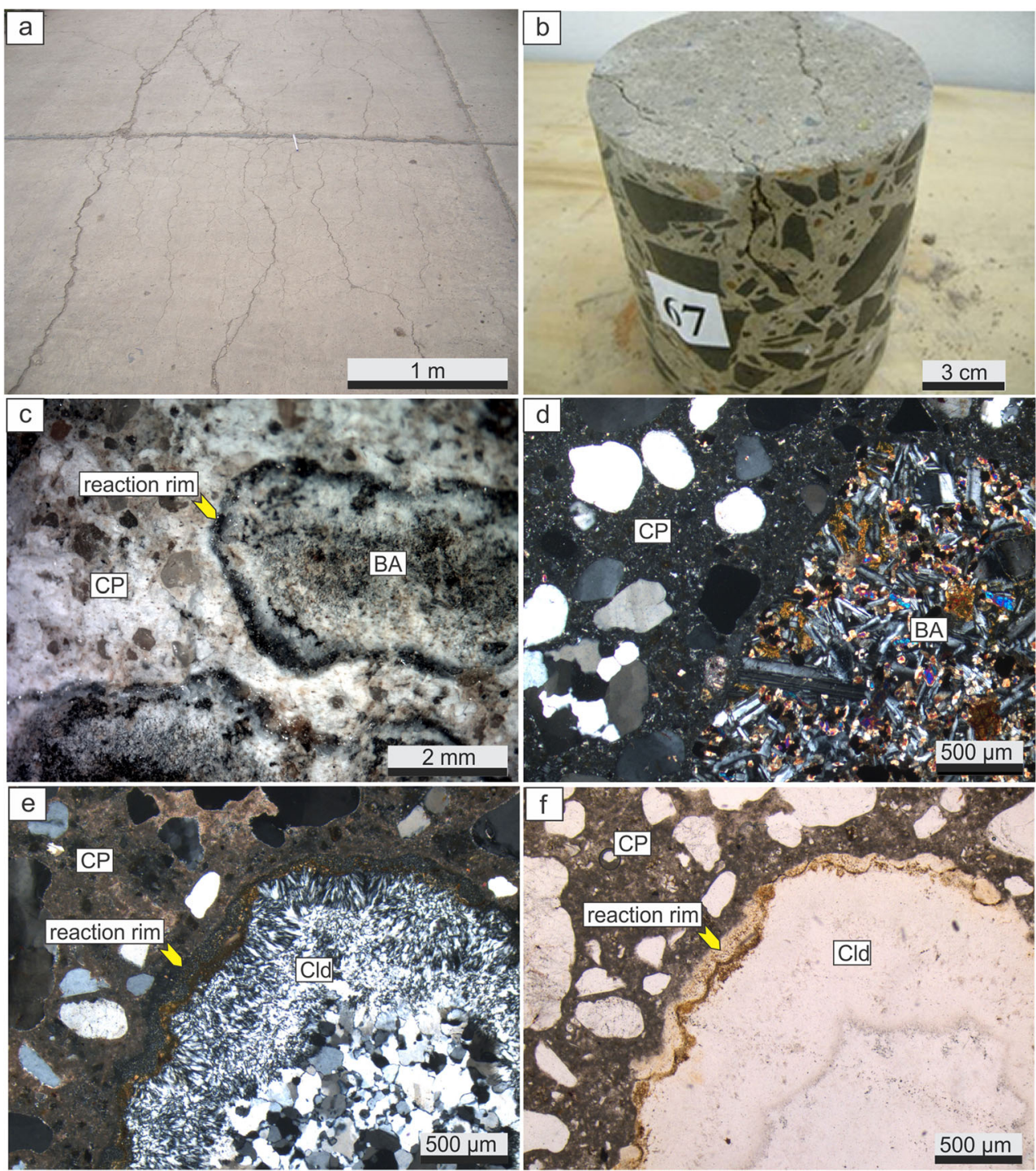
Table 8 Results of visual observation of cores

\begin{tabular}{lll}
\hline Characteristics & Type/number of cores & Deterioration degree/number of cores \\
\hline Shallow cracks & $\mathrm{D} / 5$ & $\mathrm{~S} / 2, \mathrm{M} / 1, \mathrm{~L} / 2$ \\
Mass cracks & $\mathrm{D} / 4$. (VTC/3, NVTC/1, HC/3) & $\mathrm{S} / 3, \mathrm{M} / 1$ \\
Holes & Yes, in all the cores & $\mathrm{L} / 5$ \\
Segregation & No & No \\
\hline
\end{tabular}

Types of cracks: D (cracks attributable to deleterious phenomena or durability problems), VTC (vertical through-crack) NVTC (no vertical throughcrack) $\mathrm{HC}$ (horizontal crack). Deterioration degree: $\mathrm{L}=$ light; $\mathrm{M}=$ moderate; $\mathrm{S}=$ severe

\section{Case studies}

\section{Urban concrete pavement (city of Curuzú Cuatiá)}

Structure characteristics and visual inspection The pavement has a total width of $7.40 \mathrm{~m}$, with a longitudinal joint in the center of the road and contraction joints every $5.0 \mathrm{~m}$, forming rectangular slabs of $3.70 \times 5.00 \mathrm{~m}$. In correspondence with the sidewalks, the pavement has a concrete curb integrated into the slab whose thickness varies between 13.5 and $20.5 \mathrm{~cm}$ with an average value of $15.8 \mathrm{~cm}$. Table 7 shows the results obtained from the visual inspection.

Cracks assigned to ASR phenomena have erratic distribution, although in some sectors, they are preferentially oriented in a longitudinal direction (Fig. 7a). They are empty or filled with whitish material. The cracking degree in most slabs is moderate to severe.

Visual inspection and physical properties of cores Table 8 summarizes the results of the visual observation of cores. The presence of holes is scarce, reflecting acceptable compaction conditions for the structure type. Signs of segregation were not observed. The distribution of the main components (coarse aggregate and mortar) is homogeneous. Shallow and mass cracks due to ASR are observed (Fig. 7b).

Cracks in the concrete mass are developed preferentially along horizontal planes and intercepted by vertical map cracks. Reaction rims were observed around coarse aggregate particles with exudation of whitish products filling pores and cracks (Fig. 7c). The core concrete is made of coarse aggregate of $\sim 19 \mathrm{~mm}$ maximum size.

Table 9 lists the results of the physical properties determined for the cores and subsamples obtained from them.

Petrographic characteristics and SEM-EDS analysis The coarse aggregate is the basalt from quarry A, as shown by the high percentage of clay and volcanic glass in the matrix. In addition, approximately $5 \%$ of siliceous sandstones composed of microcrystalline quartz and chalcedony are observed. The fine aggregate is natural sand consisting of quartz, siliceous and ferruginous sandstones, and chalcedony. With a petrographic microscope, reaction rims in the basaltic aggregates are not very evident (Fig. 7d), although they are well-developed in the periphery of chalcedony-rich siliceous sandstones (Fig. 7e and f) and in air voids. By SEM-EDS, massive and cracked gel-like products are recognized in the paste-aggregate interface and in air voids (Fig. 8a), which correspond to calcium silicates (probably hydrated) with smaller amounts of sodium and potassium (Fig. 8c). Lamellar to fibrous crystalline products arranged radially (Fig. 8b) are also recognized, which correspond to calcium, sodium and potassium silicates, with minor amounts of aluminum (Fig. 8d). In the paste-fine aggregate interface, a thin layer of reaction material is also recognized (Fig. 8e), corresponding

Table 9 Physical properties determined for the cores and subsamples

\begin{tabular}{|c|c|c|c|c|c|c|c|}
\hline $\begin{array}{l}\text { Core/ } \\
\text { sample }\end{array}$ & $\begin{array}{l}\text { Dry } \\
\text { density } \\
\left(\mathrm{kg} / \mathrm{m}^{3}\right)\end{array}$ & $\begin{array}{l}\text { Saturated density dry } \\
\text { surface } \\
\left(\mathrm{kg} / \mathrm{m}^{3}\right)\end{array}$ & $\begin{array}{l}\text { Absorption } \\
(\%)\end{array}$ & $\begin{array}{l}\text { Porosity } \\
(\%)\end{array}$ & $\begin{array}{l}\text { Loss on } \\
\text { ignition } \\
(\%)\end{array}$ & $\begin{array}{l}\text { Unit content of dry fine } \\
\text { aggregate } \\
\left(\mathrm{kg} / \mathrm{m}^{3}\right)\end{array}$ & $\begin{array}{l}\text { Unit content of dry coarse } \\
\text { aggregate } \\
\left(\mathrm{kg} / \mathrm{m}^{3}\right)\end{array}$ \\
\hline 1 & 2427 & 2531 & 4.3 & 10.4 & 4.4 & 758 & 1209 \\
\hline 2 & 2451 & 2535 & 3.4 & 8.4 & 4.2 & 816 & 1232 \\
\hline $3 / a$ & 2382 & 2501 & 5.0 & 11.9 & 4.3 & 848 & 1111 \\
\hline $3 / b$ & 2348 & 2472 & 5.3 & 12.4 & 4.7 & 958 & 890 \\
\hline $4 / a$ & 2445 & 2546 & 4.1 & 10.1 & 4.0 & 788 & 1199 \\
\hline $4 / b$ & 2446 & 2548 & 4.2 & 10.2 & 3.8 & 750 & 1290 \\
\hline $5 / a$ & 2460 & 2550 & 3.7 & 9.1 & 4.1 & 770 & 1273 \\
\hline $5 / \mathrm{b}$ & 2459 & 2553 & 3.8 & 9.5 & 4.1 & 774 & 1269 \\
\hline
\end{tabular}


Fig. 8 SEM-EDS. a Secondary electron image showing the cracked amorphous material. b Secondary electron image of the radially arranged fibrous crystalline material. c EDS spectrum of sector 1. d EDS spectrum of sector 2. $\mathbf{e}$ Backscattered electron image of the mortar. $\mathbf{f}$ EDS spectrum of sector 3. g EDS spectrum of sector 4. h Backscattered electron image of an air void filled with ettringite
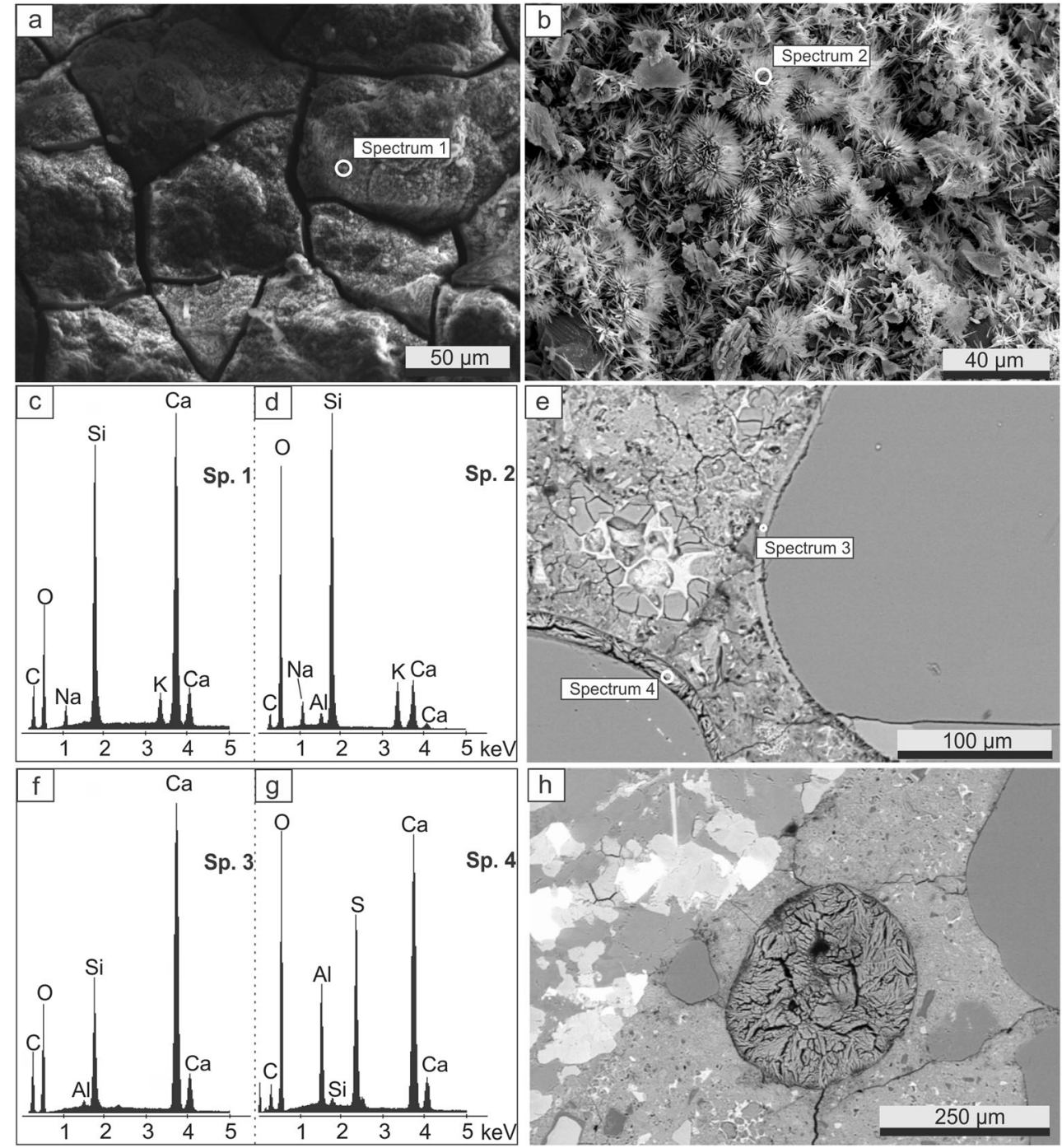

essentially to calcium silicates (Fig. 8f). The mortar presents moderate microcracking, especially in sectors where the reaction minerals are concentrated. Some microcracks are filled with ettringite (Fig. 8e and g). The entrained air voids are partially or totally filled with ettringite (Fig. 8h) and the cement paste presents low carbonation.

\section{Concrete pavement (airport of the city of Corrientes)}

Structure characteristics and visual inspection The airport is located on national route no. $12,5 \mathrm{~km}$ to the north of Corrientes city (Fig. 1a). The pavement studied is $24 \mathrm{~m}$ wide and $250 \mathrm{~m}$ long, consisting of slabs $4.0 \mathrm{~m}$ long

Table 10 Visual inspection of the concrete pavement (Corrientes Airport)

\begin{tabular}{|c|c|c|c|c|}
\hline \multirow[t]{2}{*}{ Structure } & \multicolumn{3}{|c|}{ Presence of cracks and deterioration degree } & \multirow[t]{2}{*}{ Observations } \\
\hline & $\begin{array}{l}\text { Map cracks } \\
\text { attributable to surficial } \\
\text { mortar contraction }\end{array}$ & $\begin{array}{l}\text { Plastic or } \\
\text { autogenous } \\
\text { contraction }\end{array}$ & $\begin{array}{l}\text { Map cracks } \\
\text { attributable to } \\
\text { deleterious reactions } \\
\text { (ASR) }\end{array}$ & \\
\hline $\begin{array}{l}\text { Concrete pavement } \\
\text { (Corrientes } \\
\text { Airport, } \\
\text { Argentina) }\end{array}$ & Yes - M & No & Yes - S/M & $\begin{array}{l}\text { Shallow map cracks in the mortar, of moderate severity and } \\
\text { with longitudinal extension, attributable to severe and } \\
\text { moderate deleterious reactions (ASR), with structural } \\
\text { damage. }\end{array}$ \\
\hline
\end{tabular}

Degree of cracking: $\mathrm{L}=$ light; $\mathrm{M}=$ moderate; $\mathrm{S}=$ severe 
Fig. 9 a Surface ASR cracks with whitish exudate material. b Concrete core with horizontal and vertical map cracks. c Reaction rim in basaltic aggregate with whitish material. d Ettringite partially filling an air void. e-f Photomicrographs of concrete. e Coarse basaltic aggregate in contact with highly carbonated cement paste $(\mathrm{XN})$. f Coarse basaltic aggregate with a dark reaction rim, strongly carbonated paste and cavities totally filled with ettringite $(\mathrm{XN})$. AV: air void. $\mathrm{CP}$ : cement paste. BA: basaltic aggregate
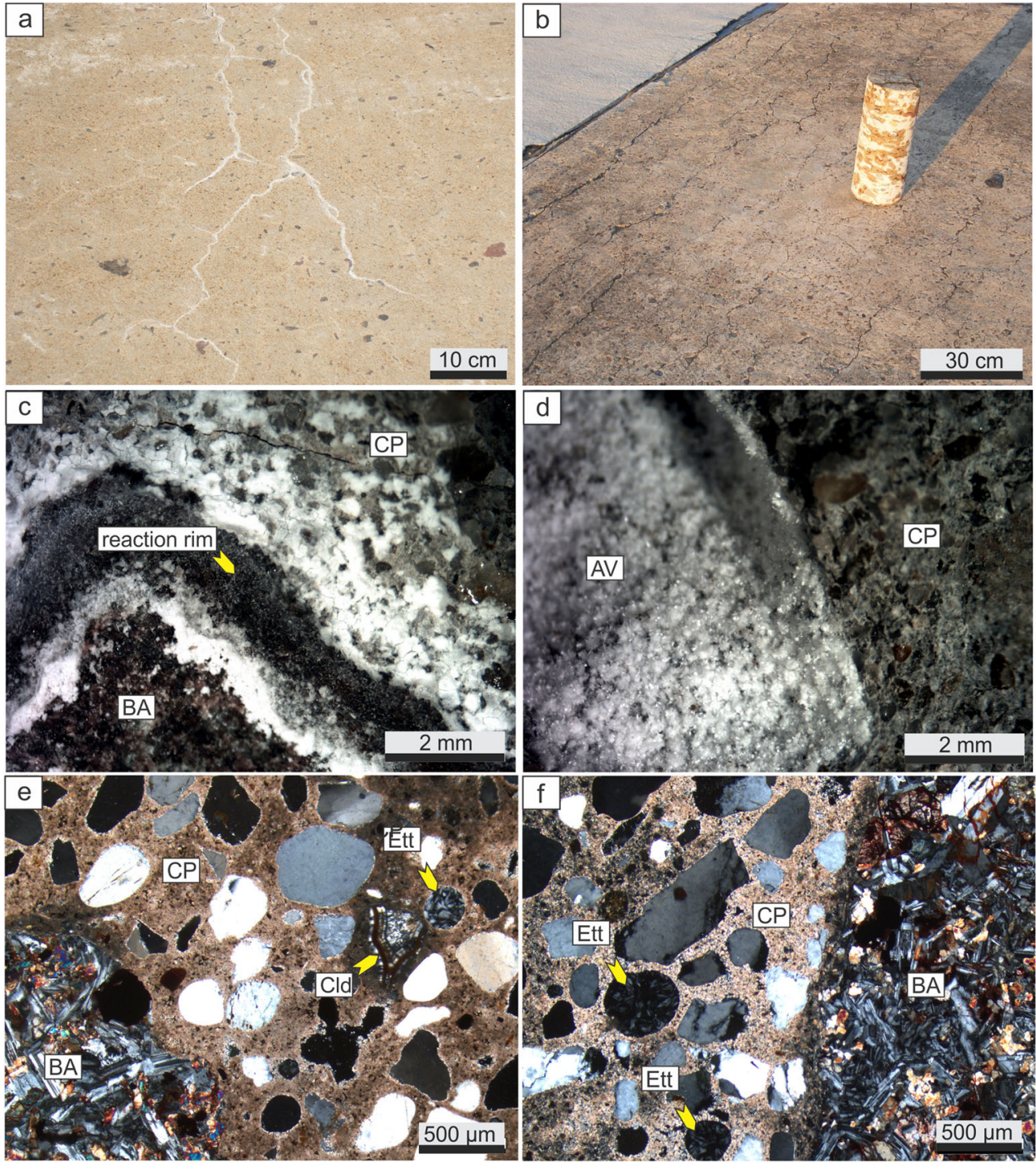

and $3.0 \mathrm{~m}$ wide. Two pavement concrete slabs corresponding to the original and repair slabs were differentiated. The concrete of the first one was made with natural gravel as coarse aggregate, while the repair slabs were manufactured from basaltic rocks. The latter were the ones selected for the study. The thickness of the slabs ranged between $31 \mathrm{~cm}$ and $36 \mathrm{~cm}$ with an average value of $33.2 \mathrm{~cm}$. Table 10 shows the results obtained from the visual inspection.

Cracks attributed to ASR phenomena have erratic map-like distribution, although in some sectors, they are oriented preferentially in a longitudinal direction. Cracks filled with whitish exudation material are common (Fig. 9a). In most slabs, the degree of cracking is moderate.

Table 11 Results of visual observation of cores

\begin{tabular}{lll}
\hline Characteristics & Type/number of cores & Deterioration degree/number of cores \\
\hline Shallow cracks & $\mathrm{D} / 5$ & $\mathrm{~S} / 4, \mathrm{~L} / 1$ \\
Mass cracks & $\mathrm{D} / 4$ (VTC/1, NVTC/3, HC/4) & $\mathrm{S} / 3, \mathrm{M} / 1$ \\
Holes & Yes, in all the cores & $\mathrm{S} / 1, \mathrm{~L} / 4$ \\
Segregation & No & No
\end{tabular}

Types of cracks: D (cracks attributable to deleterious phenomena or durability problems), VTC (vertical through-crack) NVTC (no vertical throughcrack) HC (horizontal crack). Deterioration degree: $\mathrm{L}=$ light; $\mathrm{M}=$ moderate; $\mathrm{S}=$ severe 
Table 12 Physical properties determined for the cores and subsamples

\begin{tabular}{llllllll}
\hline $\begin{array}{l}\text { Core/ } \\
\text { sample }\end{array}$ & $\begin{array}{l}\text { Dry } \\
\text { density } \\
\left(\mathrm{kg} / \mathrm{m}^{3}\right)\end{array}$ & $\begin{array}{l}\text { Saturated density dry } \\
\text { surface } \\
\left(\mathrm{kg} / \mathrm{m}^{3}\right)\end{array}$ & $\begin{array}{l}\text { Absorption } \\
(\%)\end{array}$ & $\begin{array}{l}\text { Porosity } \\
(\%)\end{array}$ & $\begin{array}{l}\text { Loss on } \\
\text { ignition } \\
(\%)\end{array}$ & $\begin{array}{l}\text { Unit content of dry fine } \\
\text { aggregate } \\
\left(\mathrm{kg} / \mathrm{m}^{3}\right)\end{array}$ & $\begin{array}{l}\text { Unit content of dry coarse } \\
\text { aggregate } \\
\left(\mathrm{kg} / \mathrm{m}^{3}\right)\end{array}$ \\
\hline $1 / \mathrm{a}$ & 2351 & 2482 & 5.6 & 13.1 & 4.3 & 820 & 1112 \\
$1 / \mathrm{b}$ & 2381 & 2498 & 4.9 & 11.7 & 4.1 & 827 & 1153 \\
$2 / \mathrm{a}$ & 2348 & 2476 & 5.5 & 12.8 & 4.4 & 893 & 1023 \\
$2 / \mathrm{b}$ & 2387 & 2504 & 4.9 & 11.7 & 4.1 & 889 & 7115 \\
$3 / \mathrm{a}$ & 2251 & 2403 & 6.8 & 15.2 & 5.0 & 1023 & 1100 \\
$3 / \mathrm{b}$ & 2348 & 2478 & 5.5 & 13.0 & 4.0 & 853 & 951 \\
$4 / \mathrm{a}$ & 2294 & 2425 & 5.7 & 13.0 & 3.7 & 796 & 1124 \\
$4 / \mathrm{b}$ & 2284 & 2417 & 5.8 & 13.3 & 3.8 & 931 & \\
\hline
\end{tabular}

Visual inspection and physical properties of cores Table 11 summarizes the results of the core visual observation. The presence of holes is scarce, reflecting acceptable compaction conditions for this type of structure. No signs of segregation were observed. The distribution of the main components (coarse aggregate and mortar) is homogeneous. Some cores present erratic map cracks on the surface, without penetrating in depth. They are attributable to
Fig. 10 SEM-EDS. a Secondary electron image of the cracked amorphous material. $\mathbf{b}$ Backscattered electron image of a filled crack inside the basaltic aggregate. $\mathbf{c}$ Backscattered electron image of the pastebasaltic aggregate interface. $\mathbf{d}$ EDS spectrum of sector 1. e EDS spectrum of sector 2. f EDS spectrum of sector 3. g EDS spectrum of sector 4 . $\mathbf{h}$ Secondary electron image of an air void filled with ettringite
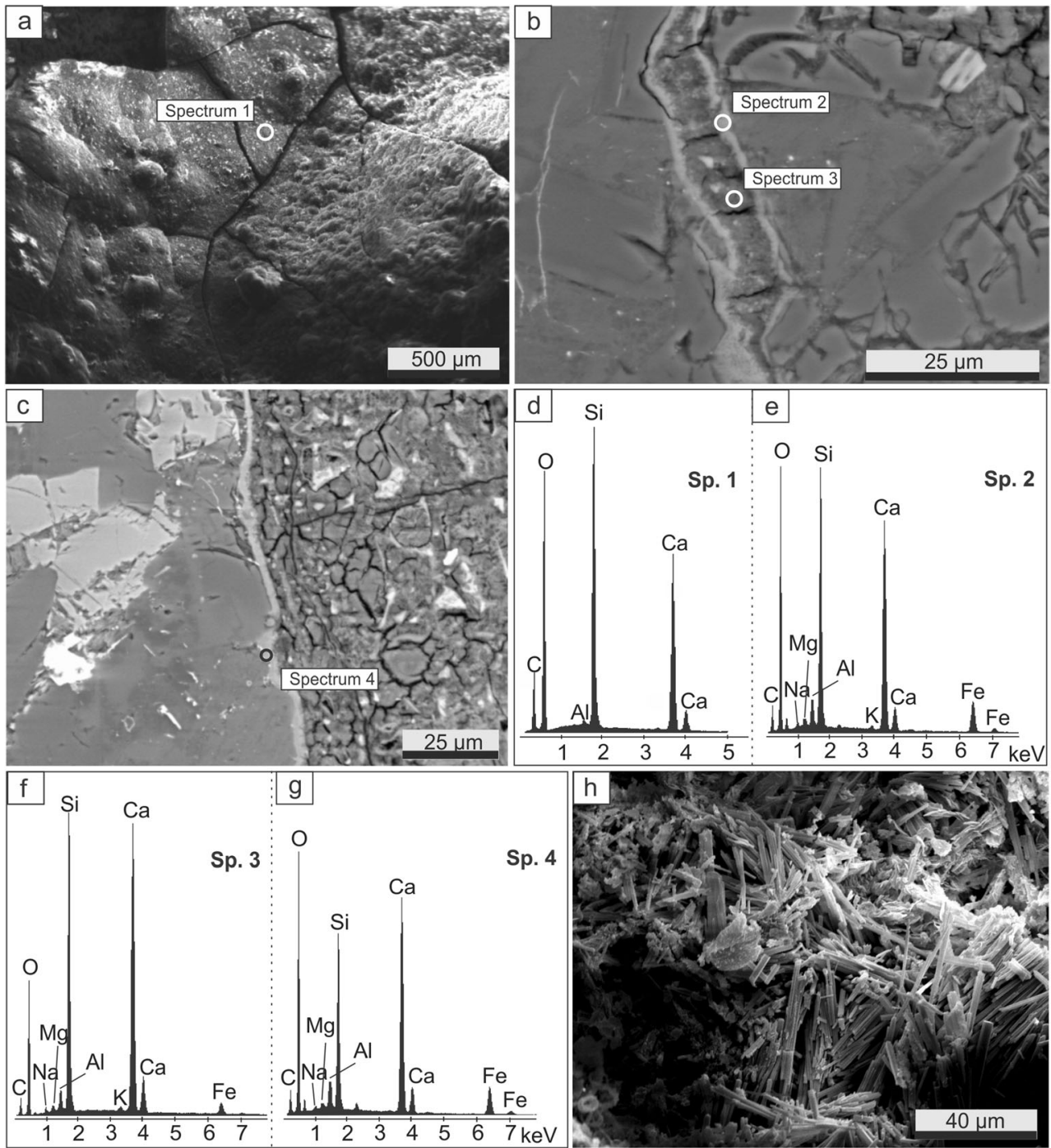

9
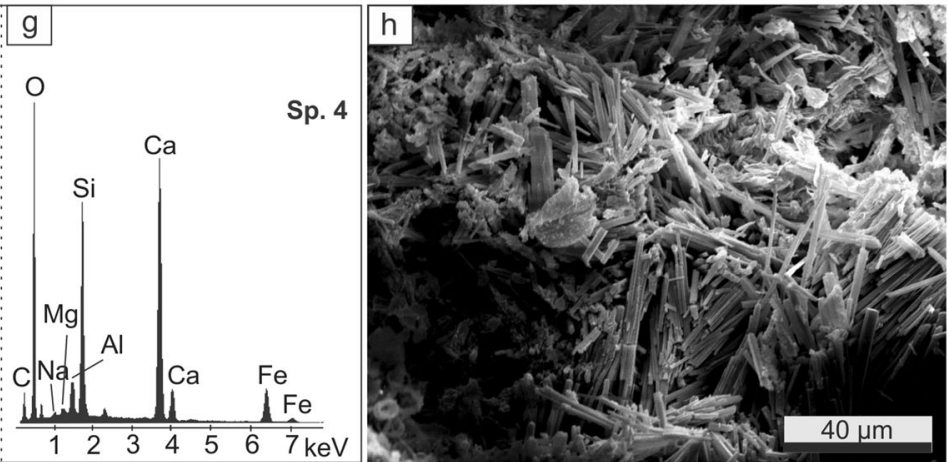


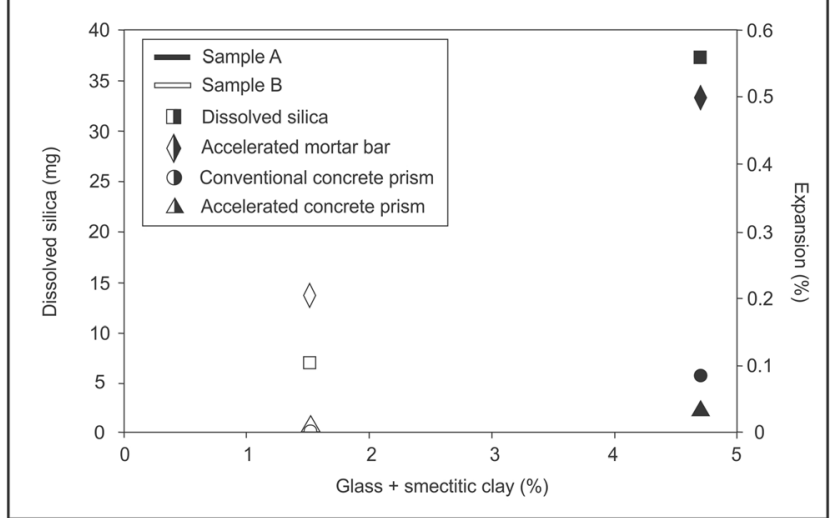

Fig. 11 Relationship between the results of physical and chemical tests of samples A and B, and glass + smectitic clay contents (\%)

surface phenomena of contraction. Some cores present superficial cracks in the mass associated with ASR with whitish exudate material. The cracks are mainly developed along horizontal planes and are intersected by vertical map cracks, some of them through the aggregates (Fig. $9 b)$. Reaction rims are observed around coarse aggregate particles with associated whitish exudation products (Fig. 9c). The paste is carbonated and the air voids are generally partially or totally filled with ettringite (Fig. 9d). The concrete of the extracted core contains coarse aggregate of $37.5 \mathrm{~mm}$ maximum size. Table 12 shows the results of the physical properties determined for the cores and subsamples obtained from them.

Petrographic characteristics and SEM-EDS analysis The coarse aggregate is composed of quarry B basalt. Sixty percent of the coarse aggregates have a great amount of iron oxides/hydroxides, giving them a reddish-brown color. The fine aggregate is natural sand composed of quartz, siliceous and ferruginous sandstones, and chalcedony. The aggregates present scarce reaction rims; however, the main characteristic of the concrete studied is the strong carbonation of the cement paste and the presence of ettringite, widely distributed, filling cracks and empty spaces. SEMEDS studies revealed the presence of whitish material associated with the reaction rims with massive appearance and cracked (Fig. 10a), which corresponds to calcium silicates, probably hydrated (Fig. 10d). Inside the coarse aggregates, some cracks filled with a cracked fine-grained material are observed (Fig. 10b). On both sides of the crack, the material is composed of calcium silicate with minor amounts of aluminum, iron, sodium and potassium (Fig. 10e). Inside the crack, the material has similar composition, although with lower iron content and higher calcium content (Fig. 10f). In the paste-aggregate interface (Fig. 10c), a material of similar composition is also recognized (Fig. 10g). The air voids are filled with ettringite (Fig. 10h).

\section{Discussion}

The results of the accelerated tests (mortar bar and concrete prism) and the conventional concrete prism test are not coincident in terms of the qualification of the samples with respect to their potential reactivity, as mentioned by other authors for this type of rock (Couto 2008; Sanchez 1988). However, in general, there is a direct relationship between the results of physical and chemical tests and glass + smectitic clay contents (Fig. 11).

Although sample A has lower silica content than sample B $\left(\mathrm{SiO}_{2}=49.61 \%\right.$ vs. $55.19 \%$ by weight, respectively $)$, the former has the highest percentage of volcanic glass $(2.5 \%$ vs. $0.5 \%$, respectively) and higher silica release (dissolved silica $=$ $37 \mathrm{mg}$ vs. $7 \mathrm{mg}$, respectively). This is undoubtedly the reason why all the physical tests show that quarry A aggregates are more reactive than those from quarry $\mathrm{B}$. So the basaltic aggregates cannot be qualified using the chemical analysis of bulk samples, since their petrographic, mineralogical and textural characteristics are determining factors for evaluating their potential reactivity. Although the content of glass $(0.5 \%)$ and smectites $(<1 \%)$ in the aggregates from quarry $\mathrm{B}$ is very low, the sample qualifies as potentially reactive in the accelerated mortar bar test. This behavior can be explained by the presence of microcrystalline quartz in the rock matrix, which would have reacted quickly in conjunction with other phases of mesostasis, contributing to the early expansion recorded in the accelerated mortar bar test, similarly to those proposed by Tiecher et al. (2012).

According to the results of the concrete prism test (which is generally taken as a reference to evaluate the potential alkali reactivity), the sample from quarry A must be classified as potentially reactive, while the sample from quarry B as nonreactive. The accelerated concrete prism test qualifies both samples as nonreactive according to the IRAM 1700 (2013) standard $(<0.04 \%$ at 13 weeks), but at this time, aggregates from quarry A continue expanding. If the limit set by RILEM at 15 weeks (0.03\%; Nixon and Sims 2016) is considered, this sample should be qualified as potentially reactive, in agreement with the conventional concrete prism method. This accelerated method is highly promising and begins to be recommended due to its good repeatability and reproducibility, and because it gives relatively rapid results (Lindgård et al. 2010). However, ASR was identified in the two structures studied.

On the one hand, the concrete of the urban pavement of the city of Curuzú Cuatiá presents high density and low porosity and absorption, which is consistent with the low paste carbonation and the poor development of secondary ettringite. However, the presence of quarry A aggregates and, in particular, the mixing with $5 \%$ of siliceous sandstones rich in chalcedony as coarse aggregate would have favored ASR development and the marked deterioration of the structure. Moreover, expandable clays would also have participated in 
the processes associated with ASR, as proposed by other authors for this type of rock (Batic et al. 1994). The pavement concrete of Corrientes city airport presents lower density with greater absorption and porosity, which is evidenced in the strong paste carbonation and the great distribution of ettringite in cracks and air voids. Although the concrete was manufactured with quarry B aggregates, qualified as nonreactive according to the conventional concrete prism test, the lower quality of the concrete would have favored the entry of moisture into the structure to react with the small amount of glass in the rock together with the microcrystalline quartz of the mesostasis and the chalcedony present in the fine aggregate, being sufficient sources for the development of the reaction products associated with the ASR. However, in this structure, ASR does not seem to be the cause of the initial deterioration, but a consequence of the loss of concrete quality.

\section{Conclusions}

1. Aggregates from quarry A are classified as potentially alkali-reactive according to the accelerated mortar bar method and the conventional concrete prism test. At 13 weeks, the expansion determined in the accelerated concrete prism method $(0.030 \%)$ does not exceed the limit of $0.04 \%$ established by the standard, although the expansion does not stabilize and reaches $0.035 \%$ and $0.037 \%$ at 15 and 20 weeks, respectively. The cause of this behavior is attributed to the presence of volcanic glass (2.5\%), which would have been the source of silica for ASR development. Probably, there is also participation of expandable clays (2.2\%), although additional studies are needed to understand the role of these smectites in the deterioration processes.

2. The aggregates from quarry B are classified as nonreactive according to the conventional and accelerated concrete prism methods, while in the accelerated mortar bar test, they are classified as potentially reactive. The content of glass and clays recognized in the mesostasis of the aggregates is very low $(0.5 \%$ and $<1 \%$, respectively); however, other components such as microcrystalline quartz in the rock matrix could have contributed to the early expansion recorded in the accelerated mortar bar test.

3. In the two concrete structures studied, ASR was determined, although with different degrees of intensity. The pavement concrete of the city of Curuzú Cuatiá has good physical characteristics. However, the use of the basaltic aggregates from quarry $\mathrm{A}$, together with siliceous sandstones rich in chalcedony and microcrystalline quartz, would have contributed to the development of the reaction and cracking of the structure. The concrete pavement located in Corrientes Airport shows intense carbonation and cracking. The deterioration of the concrete (and its physical properties) would have favored the entry of moisture into the structure and the development of the ASR as a secondary process, due to the reaction with the mesostasis components and the coarse aggregate matrix (microcrystalline quartz) as well as to chalcedony present in the fine aggregate.

4. The conventional concrete prism test method was the only one that differentiated the reactive aggregate of quarry $\mathrm{A}$ from the nonreactive aggregate of quarry $\mathrm{B}$, in agreement with their behavior in service. The accelerated methods showed divergence in the results, although sample A was always more reactive than sample $\mathrm{B}$. The accelerated concrete prism test is promising in order to obtain relatively fast results; however, further research is needed in order to adjust the expansion limit considered and the age of testing.

Acknowledgments Financial support was provided by Dirección de Vialidad Nacional, Project "Control de la reacción álcali agregado en hormigones elaborados con agregados basálticos de la Mesopotamia Argentina destinado a obras viales de hormigón". The authors thank CICTERRA (CONICET-UNC), CIC (province of Buenos Aires), Facultad de Ingeniería - UNLP and the Geology Department of Universidad Nacional del Sur for their support. The authors thank the anonymous reviewers for their valuable comments which helped to improve the manuscript.

\section{References}

American Concrete Institute (ACI) (1992) Guide to durable concrete. ACI Manual of Concrete Practice 201.2R-92, Committee 201, ACI, Farmington Hills, MI

ASTM C 289 (2007) Standard test method for potential alkali-silica reactivity of aggregates (Chemical Method) (Withdrawn 2016). ASTM International, West Conshohocken, PA, p 7

ASTM C1260 (2014) Standard test method for potential alkali reactivity of aggregates (mortar-bar method). ASTM International, West Conshohocken, p 5

ASTM C1293 (2018) Standard test method for determination of length change of concrete due to alkali-silica reaction. ASTM International, West Conshohocken, $\mathrm{p} 7$

ASTM C295 (2008) Standard guide for petrographic examination of aggregates for concrete. ASTM International, West Conshohocken, p 9

ASTM C642 (2013) Standard test method for density, absorption, and voids in hardened concrete. ASTM International, West Conshohocken, $\mathrm{p} 3$

Batic O, Maiza P, Sota J (1994) Alkali silica reaction in basaltic rocks NBRI method. Cem Concr Res 24(7):1317-1326

Broekmans MATM, Jansen JBH (1998) Silica dissolution in impure sandstone: application to concrete. J Geochem Explor 62(1-3): $311-318$

Couto TA (2008) Alkali-aggregate reaction: a study of the phenomenon in siliceous rocks. Masters of Science Thesis, Universidade Federal de Goiás, Brazil

Favetto A, Pomposiello C (2010) Modelo geoeléctrico de la cuenca chacoparanense en Santa Fe-Entre Ríos a partir de un estudio magnetotelúrico. Rev Asoc Geol Argent 67(1):130-138 
Favetto A, Pomposiello C, Benedit T, Booker J (2004) Magnetotelluric model of the Chacoparenense sedimentary basin at $31.5 \mathrm{~S}$, Argentina. In: 17th International Workshop on Electromagnetic Induction in the Earth, India, S-1 P-58, p 77-78

Fili M, Da Rosa Filho E, Auge M, Montaño Xavier J, Tujchneider O (1998) El acuífero Guaraní. Un recurso compartido por Argentina, Brasil, Paraguay y Uruguay (América del Sur). Instituto Tecnológico Geominero de España. Bol Geol Min 109(4):389-394

Goguel R (1995) Alkali release by volcanic aggregate in concrete. Cem Concr Res 25(4):841-852

Gomes MEB (1996) Mecanismos de resfriamento, estruturação e processos pós-magmáticos em basaltos da Bacia do Paraná Região de Frederico Westphalen (RS) - Brasil. PhD Thesis, Universidade Federal do Rio Grande do Sul, Brazil

Guömundsson G, Ásgeirsson H (1975) Some investigations on alkali aggregate reaction. Cem Concr Res 5(3):211-219

Ichikawa T, Miura M (2007) Modified model of alkali-silica reaction. Cem Concr Res 37(9):1291-1297

IRAM 1531 (2016) Agregado grueso para hormigón de cemento. Instituto Argentino de Racionalización de Materiales (IRAM), $33 \mathrm{p}$

IRAM 1551 (2000) Hormigón de cemento pórtland. Extracción, preparación y ensayo de testigos de hormigón endurecido. Instituto Argentino de Racionalización de Materiales (IRAM), $12 \mathrm{p}$

IRAM 1649 (2008) Examen petrográfico de agregados para hormigón. Instituto Argentino de Racionalización de Materiales (IRAM), $13 \mathrm{p}$

IRAM 1650 (1968) Reactividad alcalina potencial en agregados. Método de ensayo químico. Instituto Argentino de Racionalización de Materiales (IRAM), $15 \mathrm{p}$

IRAM 1674 (1997) Agregados. Determinación de la reactividad alcalina potencial. Método acelerado de la barra del mortero. Instituto Argentino de Racionalización de Materiales (IRAM), $15 \mathrm{p}$

IRAM 1700 (2013) Agregados. Determinación del cambio de longitud debido a la reacción álcali-agregado, en prismas de hormigón. Instituto Argentino de Racionalización de Materiales (IRAM), $16 \mathrm{p}$

Katayama T, St John DA, Futagawa T (1989) The petrographic comparison of some volcanic rocks from Japan and New Zealand - potential reactivity related to interstitial glass and silica minerals. In: Okada K, Nishibayashi S, Kawamura M (eds) Proceedings of the 8th International Conference on Alkali-Aggregate Reaction, Kyoto, Japan, p 537-542

Katayama T, Helgason TS, Olafsson H (1996) Petrography and alkalireactivity of some volcanic aggregates from Iceland. In: Shayan A (ed). Proceedings of the 10th International Conference on AlkaliAggregate Reaction, Melbourne, Australia, p 377-384

Korkanç M, Tuğrul A (2005) Evaluation of selected basalts form the point of alkali-silica reactivity. Cem Concr Res 35(3):505-512

Le Bas MJ, Le Maitre RW, Streckeisen A, Zanettin B (1986) A chemical classification of volcanic rocks based on the total alkali-silica diagram. J Petrol 27(3):745-750

Leemann A, Holzer L (2005) Alkali-aggregate reaction-identifying reactive silicates in complex aggregates by ESEM observation of dissolution features. Cem Concr Res 27(7-8):796-801

Lindgård J, Nixon PJ, Borchers I, Schouenborg B, Wigum BJ, Haugen M, Ákesson U (2010) The EU partner project - European standard tests to prevent alkali reactions in aggregates. Cem Concr Res 40(4): 611-635

Marfil SA, Maiza PJ (2001) Deteriorated pavements due to the alkalisilica reaction: a petrographic study of three cases in Argentina. Cem Concr Res 31(7):1017-1021

Marfil SA, Maiza PJ, Bengochea AL, Sota JD, Batic OR (1998) Relationships between $\mathrm{SiO}_{2}, \mathrm{Al}_{2} \mathrm{O}_{3}, \mathrm{Fe}_{2} \mathrm{O}_{3}, \mathrm{CaO}, \mathrm{K}_{2} \mathrm{O}$, and expansion in determination of the alkali reactivity of basaltic rocks. Cem Concr Res 28(2):189-196

Marfil S, Batic O, Maiza P, Grecco L, Falcone D (2010) Comportamiento de rocas basálticas de las Prov. de Corrientes y Entre Ríos frente a la reacción álcali-sílice. In: VI Congreso Uruguayo de Geología, Parque UTE Lavalleja, Uruguay, $6 \mathrm{p}$

Montaño J, Tujchneider O, Auge M, Fili M, Paris M, D’Elía M, Pérez M, Nagy MI, Collazo P, Decoud P (1998) Acuíferos regionales en América Latina. Sistema Acuífero Guaraní. Capítulo argentinouruguayo. Centro de Publicaciones, Universidad Nacional del Litoral, Santa Fe, $217 \mathrm{p}$

Munhoz FAC, Kihara Y, Cincotto MA (2008) Effect of mineral admixtures on to the mitigation of alkali-silica reaction in concrete. In: Broekmans MA, Wigum BJ (eds) Proceedings of the 13th International Conference Alkali-Aggregate Reaction, Trondheim, Norway, p 591-599

Nixon PJ, Sims I (2016) RILEM Recommended Test Method: AAR-4.1 - Detection of Potential Alkali-Reactivity $-60{ }^{\circ} \mathrm{C}$ Test Method for Aggregate Combinations Using Concrete Prisms. In: RILEM Recommendations for the Prevention of Damage by AlkaliAggregate Reactions in New Concrete Structures. Dordrecht, Springer, $p$ 99-116

Pezzi EE, Mozetic ME (1989) Cuencas sedimentarias de la región chacoparanense. Cuencas Sedimentarias Argentinas, Serie Correlación Geológica 6:65-78

Rocco C, Maiza P, Fava C, Marfil S, Tobes J (2012) Estudio de reactividad alcalina potencial de basaltos procedentes de yacimientos ubicados en la Mesopotamia Argentina. In: V Congreso Internacional de la AATH y $19^{\circ}$ Reunión Técnica. Actas. Bahía Blanca, p 159-166

Román HJM, Camacho RER, Afi, RU, Martínez G, Rodriguez DR (2008) Evaluation of alkali-aggregate reaction in aggregates from igneous rocks. In: Broekmans MA, Wigum BJ (eds) Proceedings of the 13th International Conference on Alkali-Aggregate Reaction, Trondheim, Norway, p 310-319

Sanchez LM (1988) Contribution to the study of test methods in assessing alkali aggregate reactions in concrete. Master of Science Thesis, Universidade de São Paulo, Brazil

Shayan A, Quick GW (1988) An alkali-reactive basalt from Queensland, Australia. Int J Cem Compos Lightweight Concrete 10(4):209-214

Silva Busso A (1999) Contribución al conocimiento de la geología e hidrogeología del sistema acuífero termal de la cuenca Chacoparanense oriental argentina. PhD thesis, Facultad de Ciencias Exactas y Naturales. Universidad de Buenos Aires, Buenos Aires, $480 \mathrm{p}$

St John DA, Poole AB, Sims I (1998) Concrete petrography: a handbook of investigative techniques, 1st edn. Edward Arnold, London

Tiecher F (2006) Alkali-aggregate reaction: evaluation on the behavior of the aggregates from southern region of Brazil when different types of Portland cements are applied. Master of Science Thesis, Universidade Federal do Rio Grande do Sul, Porto Alegre, Brazil

Tiecher F, Gomes MEB, Dal Molin DCC, Hasparyk NP, Monteiro PJM (2009) Influence of microcrystalline material into volcanic rocks for alkali-aggregate reaction. In: 59th Congresso Brasileiro do Concreto, Curitiba, Brazil

Tiecher F, Dal Molin DCC, Gomes MEB, Hasparyk NP, Monteiro PJM (2012) Influence of mesostasis in volcanic rocks on the alkaliaggregate reaction. Cem Concr Compos 34(10):1130-1140

Valduga L, Dal Molin DCC, Paulon VA (2006) Basalts potential reactivity survey in Brazil. In: 2nd Simpósio sobre reação álcali-agregado em estruturas de concreto, Rio de Janeiro, Brazil

Vola G, Berra M, Rondena E (2011) Petrographic quantitative analysis of ASR susceptible Italian aggregates for concrete. In: Proceedings of the 13th Euroseminar on Microscopy Applied to Building Materials, Ljubljana, Slovenia, $10 \mathrm{p}$

Wakizaka Y (2000) Alkali-silica reactivity of Japanese rocks. Eng Geol $56(1-2): 211-221$

Whitney DL, Evans BW (2010) Abbreviations for names of rock-forming minerals. Am Mineral 95(1):185-187 